\title{
Effects of Exogenous Growth Hormone on Growth Hormone-Insulin-Like Growth Factor Axis of Human Gastric Cancer Cell
}

\author{
Daoming Liang*, Yi Zhang, Jiayong Chen, Hua Wang, Tao Huang, Xin Xue \\ Gastrointestinal Surgery Department, Second Affiliated Hospital of Kunming Medical University, Kunming, China \\ Email: ${ }^{*}$ daomingliang@sina.cn
}

Received 26 October 2014; revised 30 November 2014; accepted 4 December 2014

Copyright (C) 2014 by authors and Scientific Research Publishing Inc.

This work is licensed under the Creative Commons Attribution International License (CC BY). http://creativecommons.org/licenses/by/4.0/

(c) (i) Open Access

\section{Abstract}

Aim: To study effects of recombinant human growth hormone (rhGH) on growth hormone-insulin-like growth factor axis (GH-IGFs) of human gastric cancer cell in vivo in order to reveal part mechanism of growth effects of rhGH on gastric cancer. Methods: Nude mice were randomly divided into control group, cisplatin (DDP) group, rhGH group and DDP + rhGH group after human gastric cancer xenograft model of node mice was successfully founded and drugs were used for 6 days. We investigated volume of tumor, inhibitory rate of tumor and cell cycle by slide gauge and flow cytometry. In addition, We also respectively investigated insulin-like growth factor-I (IGF-I) and insulin-like growth factor binding protein-3 (IGFBP-3) of blood serum of nude mice, IGF-ImRNA, insulin-like growth factor-I receptor (IGF-IR) mRNA and IGFBP-3 mRNA of xenograft of nude mice by enzyme linked immunosorbent assay (ELISA) and semiquantitative reverse transcriptase-polymerase chain reaction (RT-PCR) on the first day of completing use of drugs later. Results: Tumor grew obviously slowly and tumor inhibitory rate obviously rose in DDP group and DDP + rhGH group compared with control group and rhGH group $(p<0.05)$, but they were not remarkably different between DDP group and DDP + rhGH group or between control group and rhGH group. Cells of gastric cancer xenograft in $S$ phase distinctly diminished in DDP group and DDP + rhGH group compared with control group and rhGH group $(p<0.05)$, but they were not statistically significant between DDP group and DDP + rhGH group or between control group and rhGH group. IGF-I and IGFBP-3 of blood serum of nude mice obviously rose, but ratio of IGF-I and IGFBP-3 obviously lowered in rhGH group and DDP + rhGH group compared with control group and DDP group ( $p<$ 0.05). Expressions of IGF-I mRNA and IGF-IR mRNA were not obviously different in all groups. But expression of IGFBP-3 mRNA obviously increased in rhGH group, DDP group and DDP + rhGH group compared with control group; meanwhile, expression of IGFBP-3 mRNA also obviously increased in DDP + rhGH group compared with control group, DDP group and rhGH group. Conclu-

\footnotetext{
"Corresponding author.
}

How to cite this paper: Liang, D.M., Zhang, Y., Chen, J.Y., Wang, H., Huang, T. and Xue, X. (2014) Effects of Exogenous Growth Hormone on Growth Hormone-Insulin-Like Growth Factor Axis of Human Gastric Cancer Cell. Chinese Medicine, 5, 259-269. http://dx.doi.org/10.4236/cm.2014.54031 
sion: Our results indicated rhGH in short-time use did not improve proliferation of human gastric cancer cells and its mechanism was possible that rhGH in short-time use raised simultaneously IGF-I and IGFBP-3 of blood serum and increased IGFBP-3 mRNA, but degraded ratio of IGF-I and IGFBP-3 of blood serum in human gastric cancer cells.

\title{
Keywords
}

\author{
Human Growth Hormone, Stomach Neoplasm, Insulin-Like Growth Factor, Insulin-Like Growth \\ Factor Binding Protein-3, RT-Polymerase Chain Reaction
}

\section{Introduction}

The effect of growth hormone/insulin-like growth factor (GH/IGF) axis on normal cells was very clear; meanwhile, many evidences manifested that GH/IGF axis promoted growth of tumor tissue [1] [2]. Furthermore, epidemiologic survey hinted that GH/IGF axis and long-term use of growth hormone (GH) were tumorigenic possible factors. But other data showed that long-term use of GH could not promote tumorigenesis [3]-[6]. Since 1996, we have always undertaken the clinical research that recombinant human growth hormone (rhGH) was applied in postoperative patients with gastrointestinal malignant tumor for metabolic intervention. We found that rhGH improved patients' rehabilitation, raised patients living quality and did not raise relapse rate and transfer rate of cancer compared with control group [7] [8]. Lots of overseas clinical data showed that hGH did not improve cancer growth and could decrease peroperative complications incidence and death rate in postoperative patients with gastrointestinal malignant tumor [9]-[13]. Our previous empirical study has also demonstrated that rhGH did not accelerate the proliferation of human gastric cancer cell line BGC823 in vitro and in vivo [14] [15]. But mechanism that rhGH did not accelerate the proliferation of human gastric cancer cell was unknown. GH should upgrade the blood level of IGF-I by promoting the transcription and expression of IGF gene. The major effects of IGF were induced by IGF-1R. 1\% of IGF was free and effective in vivo, while 99\% was combined with insulin-like growth factor binding protein (IGFBP). It showed that IGFBP was important to the regulation of IGF effects in vivo. We analyzed contents of insulin-like growth factor-I (IGF-I), insulin-like growth factor binding protein-3 (IGFBP-3) of blood serum and expression IGF-ImRNA, insulin-like growth factor-I receptor (IGF-IR) mRNA, and IGFBP-3 mRNA of transplantation tumor of nude mice with gastric cancer after rhGH was used in nude mice for short term. Our experiment results would reveal part mechanism of growth effects of rhGH on gastric cancer.

\section{Materials and Methods}

\subsection{Materials}

$\mathrm{Nu} / \mathrm{Nu}$ nude mice were obtained from Beijing Wei Tong Li Hua experimental animal technology limited company and animal certificate number was SCXK (Jing) 2002-003. The mice were 6 wk old, with weights ranging between $15-21 \mathrm{~g}$ and they were allowed free access to the normal diets and water in specific-pathogen free laboratory in the emphasis natural drugs and pharmacology laboratory of Yunnan province China. The animal experiments were performed according to the European Community guidelines for the care and use of animals, and approved by the Animal Research Ethics Committee, Kunming Medical University. Human gastric cancer cell line MKN45 was supplied by the Cell Bank of Shanghai Cell Biology Institute of Chinese Academy of Sciences. rhGH (Saizen) was supplied by Serono (Switzerland), cisplatin (DDP) by Gejiu Biotechnology and Pharmacology Limited Company. Immunoreagent kit of insulin-like growth factor-I (IGF-I) and insulin-like growth factor binding protein-3 (IGFBP-3) was supplied by Immunodiagnostic Systems Limited, USA and 5× Reverse Transcriptase Buffer, dNTP Mixture, RNase Inhibitor, Oligo (dT) 18 Primer and AMV Reverse Primer all by Takara Biotechnology (Dalian) Limited Company. In addition, enzyme linked immunosorbent assay implement was M262154, USA. PCR implement was supplied by Biometra Company, Germany and its type was UNO-Thermoblock. 


\subsection{Methods}

The cells of human gastric cancer cell line MKN45 were cultured in laboratory and the density of single cell suspension was adjusted to $1 \times 10^{7} / \mathrm{L}$ for further use. Later, cell suspension $(0.2 \mathrm{~mL})$ was inoculated subcutaneously into right gluteal of nude mice.

After long diameter of gastric cancer xenograft was observed to be 1.0 centimeter by measuring its long diameter and short diameter, nude mice were executed and xenograft was divided into lots of mass-their volume were $2 \times 2 \times 2 \mathrm{~mm}^{3}$. Then, the mass were respectively inoculated subcutaneously into right gluteal of 30 nude mice and gastric cancer xenograft models of nude mice were founded.

On the fourteenth day of inoculation, nude mice whose xenograft grew well were randomly divided into 4 groups: control group, rhGH group, DDP group and rhGH + DDP group, and 6 in each group. Later, the following drugs were administrated for 6 consecutive days: normal saline (NS) was subcutaneously injected in control group, $0.1 \mathrm{~mL} / \mathrm{d}$; rhGH group with rhGH, $2 \mathrm{IU} / \mathrm{kg}$ per day; L-OUP group with L-OHP by celiac injection, $1.3 \mathrm{mg} / \mathrm{kg}$ per day; and rhGH + L-OHP group with both rhGH and L-OHP of the same dosage as rhGH group and L-OHP group, respectively. The nude rice was killed on the first day of completing administration.

After length and breadth of tumor were measured by slide gauge, volume of tumor was computed before use of drug. On the first day of drugs completing administration, tumor was measured by slide gauge also and volume of tumor and tumor inhibitory rate was computed. In addition, the xenograft was confirmed in pathological observation by HE dyeing. Then, 1 - $1.5 \mathrm{~mL}$ eyeballs blood of nude mice was obtained and was centrifuged $3000 \mathrm{rpm} / \mathrm{second}$ centrifugal separation of serum $10 \mathrm{~min}$, drawing the upper serum, placed in $-20^{\circ} \mathrm{C}$ refrigerator for enzyme-linked immunosorbent assay (ELISA) detection of IGF-I and IGFBP-3. ELISA detection methods include: coating, dispensing, plus HRP, substrate Yexian add color, to terminate the reaction; results found: on a white background can be a direct observation with the naked eye: the deeper the color reaction hole, the positive degree stronger negative reaction is a colorless or very light, measured by ELISA detector optical density (OD) of each hole.

Calculation formula:

$$
\text { Volume of tumor } \mathrm{V}=\mathrm{ab}^{2} / 2
$$

(V: volume of tumor, a: length of tumor, b: breadth of tumor) [16]

Tumor growth inhibitory rate $(\%)=\frac{\text { volume in control group }- \text { volume in experiment group }}{\text { volume in control group }} \times 100 \%$

Tissue of tumor was taken and was detected by flow cytometry and by reverse transcriptase-polymerase chain reaction (RT-PCR) after nude mice were killed on the first day of drugs completing administration respectively.

Flow cytometry procedures:

Part of tumor was made into a single-cell suspension for flow cytometry by grinding, centrifugating and washing. After fixed with $70 \%$ alcohol, the cells were kept at $4{ }^{\circ} \mathrm{C}$ overnight, then, dyed with fluorescence. Finally the cell cycle was examined at $488 \mathrm{~nm}$ wavelength. Barlogie cell cycle assay was used.

RT-PCR procedures:

1) Extraction of total tissue RNA

$1 \mu \mathrm{g}$ RNA was taken and the first chain of cDNA was synthesized by reverse transcription. Then, according to the instruction of AMV reverse transcriptase, the liquid was shifted in $42^{\circ} \mathrm{C}$ thermostatic bath and incubated one hour and cooling 2 minutes in ice water in turn after it was lightly stirred and was placed for 10 minutes in room temperature. The last, the reaction product was used for PCR reaction.

2) Primer sequence and reaction condition were shown in Table 1 and PCR carried out in the volume of 25 $\mu \mathrm{l}:$

PCR reaction included $94^{\circ} \mathrm{C}$ denaturing for 3 minutes and lots of cycles which were $94^{\circ} \mathrm{C}$ denaturing for 30 seconds, annealing for 30 seconds, extending $72^{\circ} \mathrm{C}$ for 30 seconds and the last extending $72^{\circ} \mathrm{C}$ for 3 minutes.

3) Electrophoresis after agarose gel electrophoresis, $5 \mu \mathrm{g} / \mathrm{mL}$ ethidium bromide dyeing for 10 minutes and pure water flush, gel was analyzed by Quantity-One software (BIO-RAD, Hercules, CA) and was image analyzed.

\subsection{Statistical Analysis}

Statistics were computed using the statistics program SPSS 13.0 software (SPSS Inc., Chicago, Ill., USA) for 
Table 1. Primer sequence and reaction conditions of RT-PCR.

\begin{tabular}{|c|c|c|c|}
\hline & Primer sequence & Annealing temperature $\left({ }^{\circ} \mathrm{C}\right)$ & Product (bp) \\
\hline IGF-1 & $\begin{array}{l}\text { ATTTCAACAAGCCCACAG } \\
\text { TCCCTCTACTTGCGTTCT }\end{array}$ & 56 & 219 \\
\hline IGF-1R & $\begin{array}{l}\text { CCTACAACATCACCGACCCG } \\
\text { CCACGACCCATTCCCAGA }\end{array}$ & 58 & 464 \\
\hline IGFBP-3 & $\begin{array}{l}\text { CCCTCTACTTGCTCGATTC } \\
\text { ACGTGCCTACCCACCTTC }\end{array}$ & 54 & 240 \\
\hline GAPDH & $\begin{array}{l}\text { GGAGCCAAACGGGTCATCATCTC } \\
\text { GAGGGGCCATCCACAGTCTTCT }\end{array}$ & 62 & 233 \\
\hline
\end{tabular}

Windows. Data are presented as mean \pm SEM and differences among experimental groups were analyzed by one-way analysis of variance or rank test. Statistical significance was set at $p<0.05$.

\section{Results}

\subsection{Pathomorphology of Xenograft by HE Dyeing}

We observed pathomorphology of xenograft in optical microscope by HE dyeing and we found that the tumor cells of xenograft were round, amount, big nucleus, more pathological division, multiple nucleoli, tumor cells arranging in disorder, plentiful blood sinusoid (Figure 1). So we thought that gastric cancer xenograft models of nude mice were successfully founded.

\subsection{Volume of Tumor and Tumor Inhibitory Rate}

Tumor grew obviously slowly and tumor inhibitory rate obviously rose in DDP group and DDP + rhGH group compared with control group and rhGH group ( $p<0.05)$; but they were not remarkably different between DDP group and DDP + rhGH group or between control group and rhGH group (Table 2).

\subsection{ELISA Detection}

As shown in Table 3, IGF-I and IGFBP-3 of blood serum of nude mice obviously stepped up in rhGH group or DDP + rhGH group compared with Control group or DDP group but ratio of IGF-I and IGFBP-3 obviously lowered and there was significant difference among them.

\subsection{Cell Cycle}

Cells of gastric cancer xenograft in S phase distinctly diminished in DDP group and DDP + rhGH group compared with control group and rhGH group $(p<0.05)$; but there was not statistically significant between DDP group and DDP + rhGH group or between control group and rhGH group (Table 4, Figure 2).

\subsection{RT-PCR Detection}

Relative abundance of mRNA was accounted in accordance with glyceraldehyde phosphate dehydrogenase (GAPDH) strap which optical density value was set for 1.000. Expression of IGF-ImRNA IGF-IR and mRNA has no statistical difference among all groups, but expression of IGFBP-3 mRNA obviously raised in DDP group, rhGH group and DDP + rhGH group compared with control group and it also obviously raised in DDP + rhGH group compared with other groups $(p<0.05)$ (Table 5, Figure 3 ).

\section{Discussions}

In our experiment, we successfully founded gastric cancer xenograft models of nude mice and cancer models were confirmed by HE dying. Then, after we detected volume of tumor, tumor growth inhibitory rate and cell cycle, we thought that the short term usage of rhGH would not accelerate the growth of human gastric cancer cells and it was in accord with our earlier studies and other data [14] [15] [17]. The results lay the foundation for next study. 


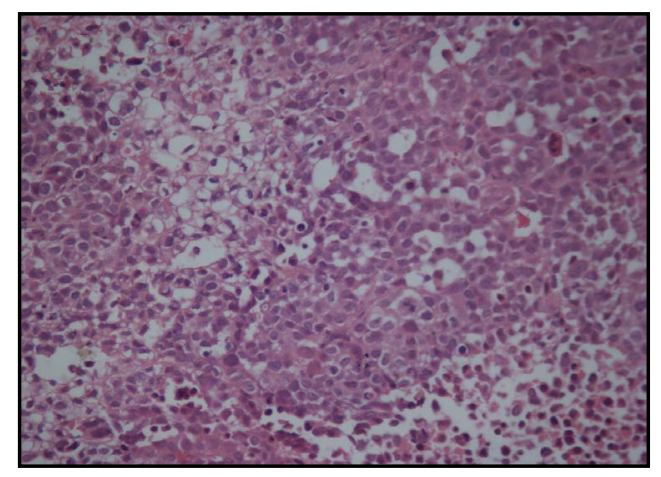

Figure 1. Pathomorphology of xenograft in control group by HE dyeing $(\times 40)$. There were big nucleus, more pathological division, multiple nucleoli, tumor cells arranging in disorder.

Table 2. Volume of tumor and tumor inhibitory rate of gastric cancer before and after use of drug.

\begin{tabular}{|c|c|c|c|}
\hline Groups & $\begin{array}{l}\text { Volume of tumor before } \\
\text { use of drug }\left(\mathrm{cm}^{3}\right)\end{array}$ & Volume of tumor after use of drug $\left(\mathrm{cm}^{3}\right)$ & Tumor inhibitory rate (\%) \\
\hline Control Group & $0.56 \pm 0.35$ & $1.54 \pm 0.96$ & 0 \\
\hline DDP Group & $0.55 \pm 0.27$ & $0.60 \pm 0.22^{*}$ & $60.75^{*}$ \\
\hline rhGH Group & $0.58 \pm 0.36$ & $1.57 \pm 0.93$ & -0.21 \\
\hline DDP + rhGH Group & $0.40 \pm 0.22$ & $0.45 \pm 0.24^{*}$ & $70.76^{*}$ \\
\hline
\end{tabular}

${ }^{*} p<0.05$, control group or rhGH group vs DDP group or DDP + rhGH group.

Table 3. IGF-I, IGFBP-3 and IGF-I/IGFBP-3 of blood serum of nude mice by ELISA ( $\bar{x} \pm \mathrm{s})$.

\begin{tabular}{cccc}
\hline Groups & IGF-I $(\mathrm{ng} / \mathrm{mL})$ & IGFBP-3 $(\mathrm{ng} / \mathrm{mL})$ & IGF-I/IGFBP-3 \\
\hline Control Group & $1727.3 \pm 69.2$ & $565.0 \pm 106.3$ & $3.20 \pm 0.94$ \\
DDP Group & $1735.3 \pm 80.2$ & $627.5 \pm 176.4$ & $2.84 \pm 0.84$ \\
rhGH Group & $1916.1 \pm 93.7^{*}$ & $1194.2 \pm 245.9^{*}$ & $1.65 \pm 0.28^{*}$ \\
DDP + rhGH Group & $1909.5 \pm 118.7^{*}$ & $1181.7 \pm 342.8^{*}$ & $1.71 \pm 0.42^{*}$ \\
\hline
\end{tabular}

${ }^{*} p<0.05$, rhGH group or DDP + rhGH group vs control group or DDP group.

Table 4. Cell cycle of gastric cancer after use of drug.

\begin{tabular}{cccc}
\hline Groups & G0-G1 phase & S phase & G2-M phase \\
\hline Control Group & $66.80 \pm 4.95$ & $11.13 \pm 5.33$ & $20.03 \pm 2.72$ \\
DDP Group & $71.33 \pm 6.23$ & $5.27 \pm 3.21^{*}$ & $23.37 \pm 3.65$ \\
rhGH Group & $66.03 \pm 5.59$ & $12.68 \pm 4.41$ & $21.28 \pm 4.11$ \\
DDP + rhGH Group & $69.87 \pm 8.51$ & $5.72 \pm 2.41^{*}$ & $24.42 \pm 10.65$ \\
\hline
\end{tabular}

${ }^{*} p<0.05$, control group or rhGH group vs DDP group or DDP + rhGH group.

Table 5. Expression of IGF-I, IGF-IR and IGFBP-3mRNA in tumor by RT-PCR.

\begin{tabular}{cccc}
\hline Groups & IGF-ImRNA & IGF-IR mRNA & IGFBP-3 mRNA \\
\hline Control Group & $0.675 \pm 0.221$ & $0.646 \pm 0.282$ & $0.021 \pm 0.001^{\#}$ \\
DDP Group & $0.724 \pm 0.224$ & $0.681 \pm 0.203$ & $0.283 \pm 0.103^{* \#}$ \\
rhGH Group & $0.566 \pm 0.184$ & $0.495 \pm 0.212$ & $0.215 \pm 0.087^{* \#}$ \\
DDP + rhGH Group & $0.618 \pm 0.243$ & $0.652 \pm 0.193$ & $0.534 \pm 0.189^{*}$
\end{tabular}

${ }^{*} p<0.05$, DDP group, rhGH group or DDP + rhGH group vs control group; ${ }^{\sharp} p<0.05$, control group, DDP group or rhGH group vs DDP + rhGH group. 


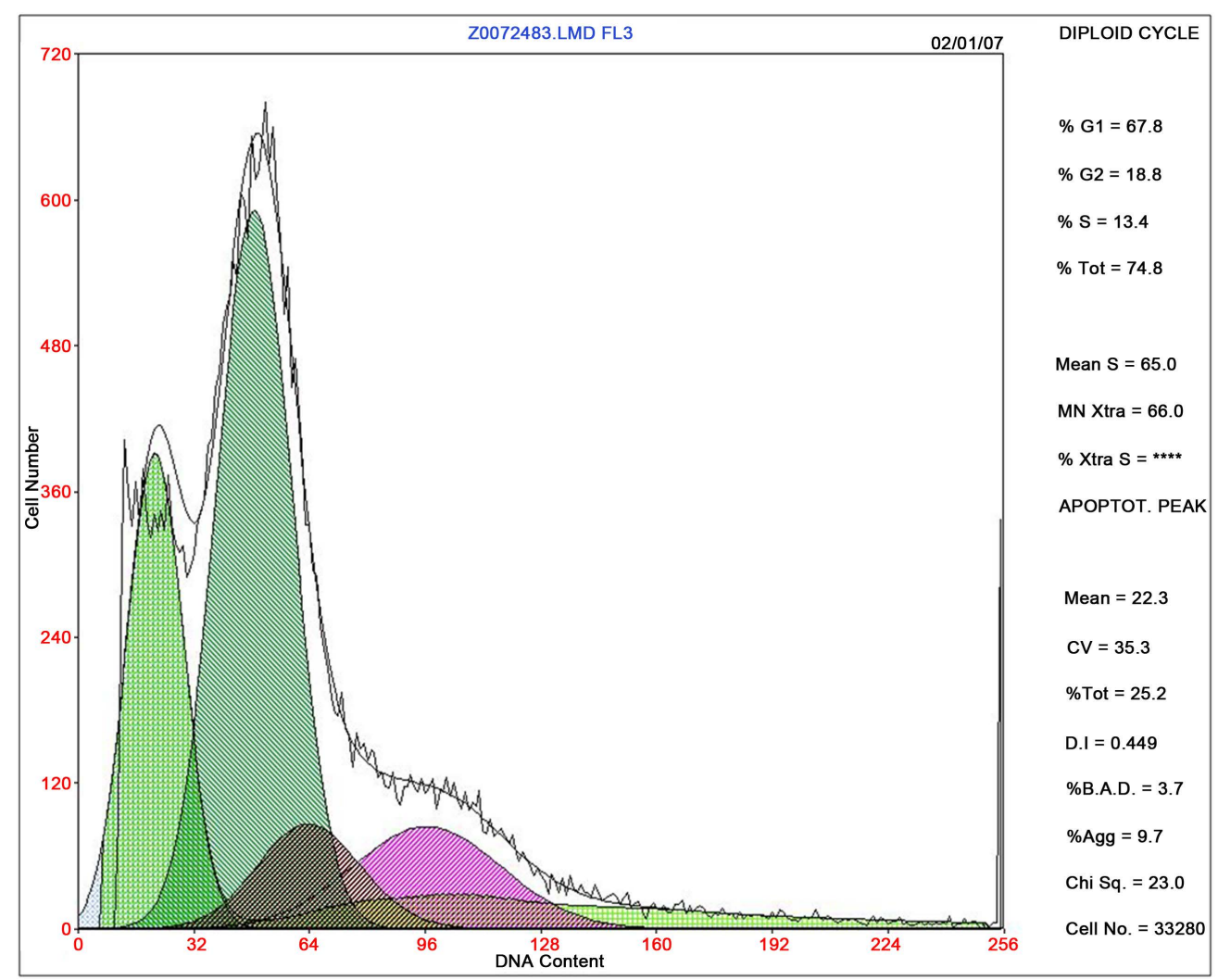

(a)

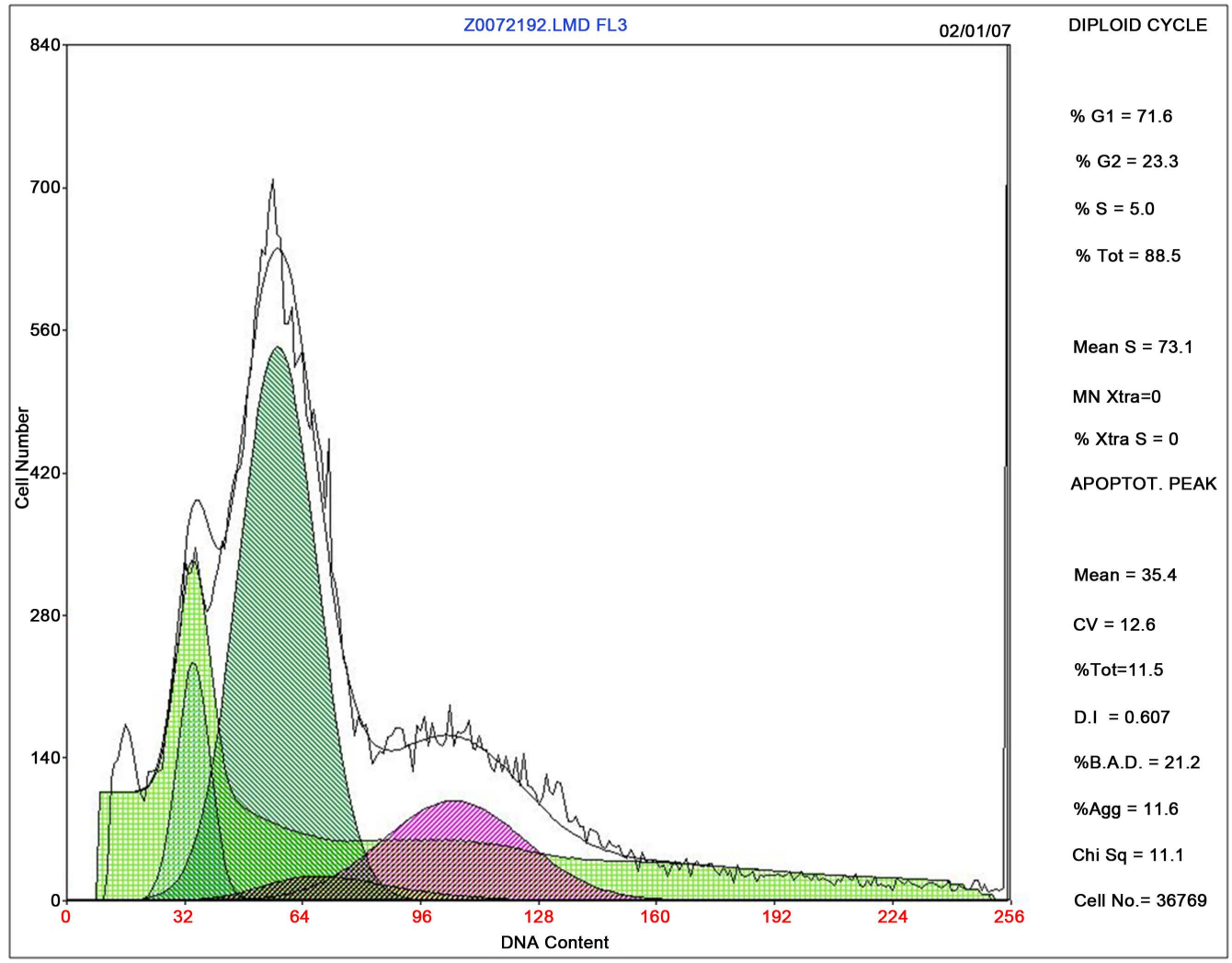

(b) 


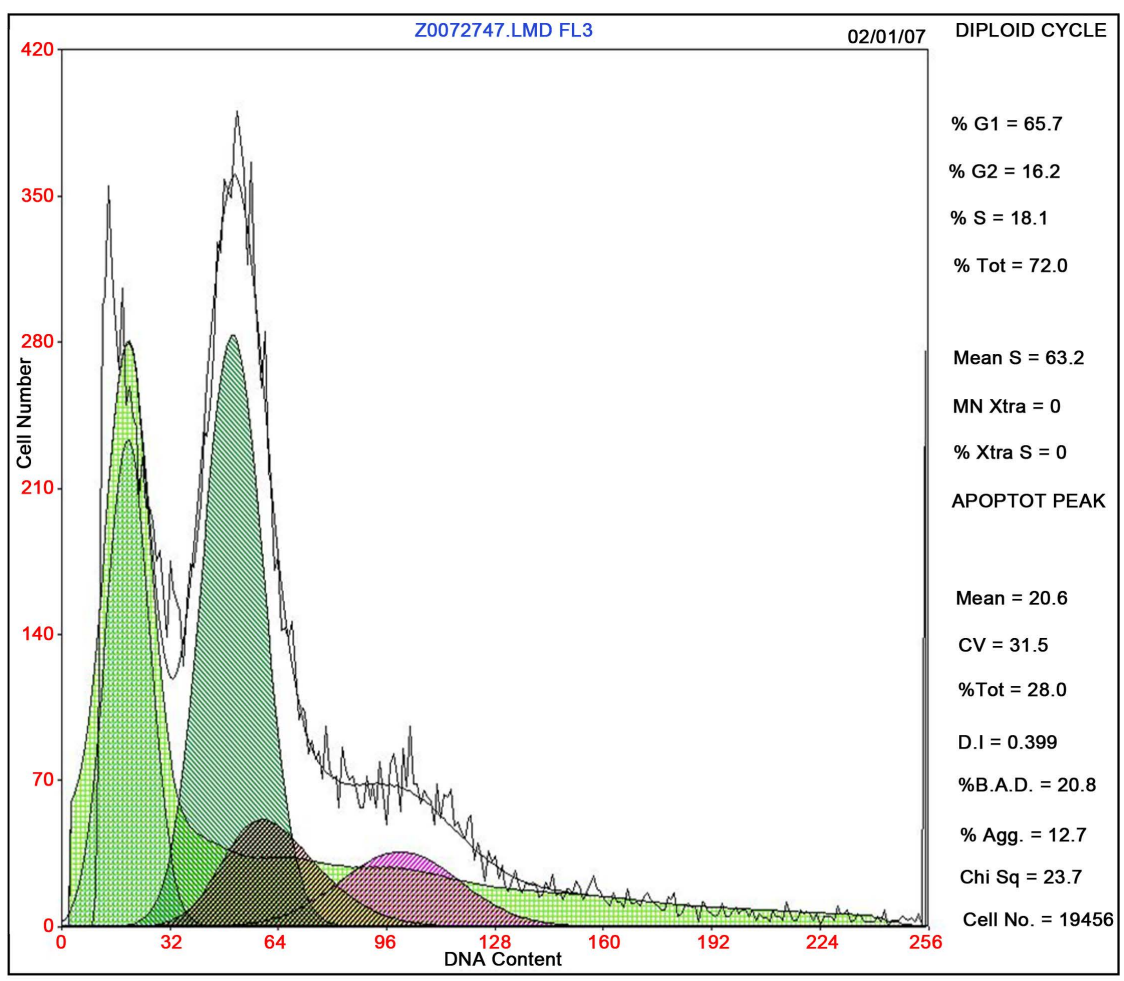

(c)

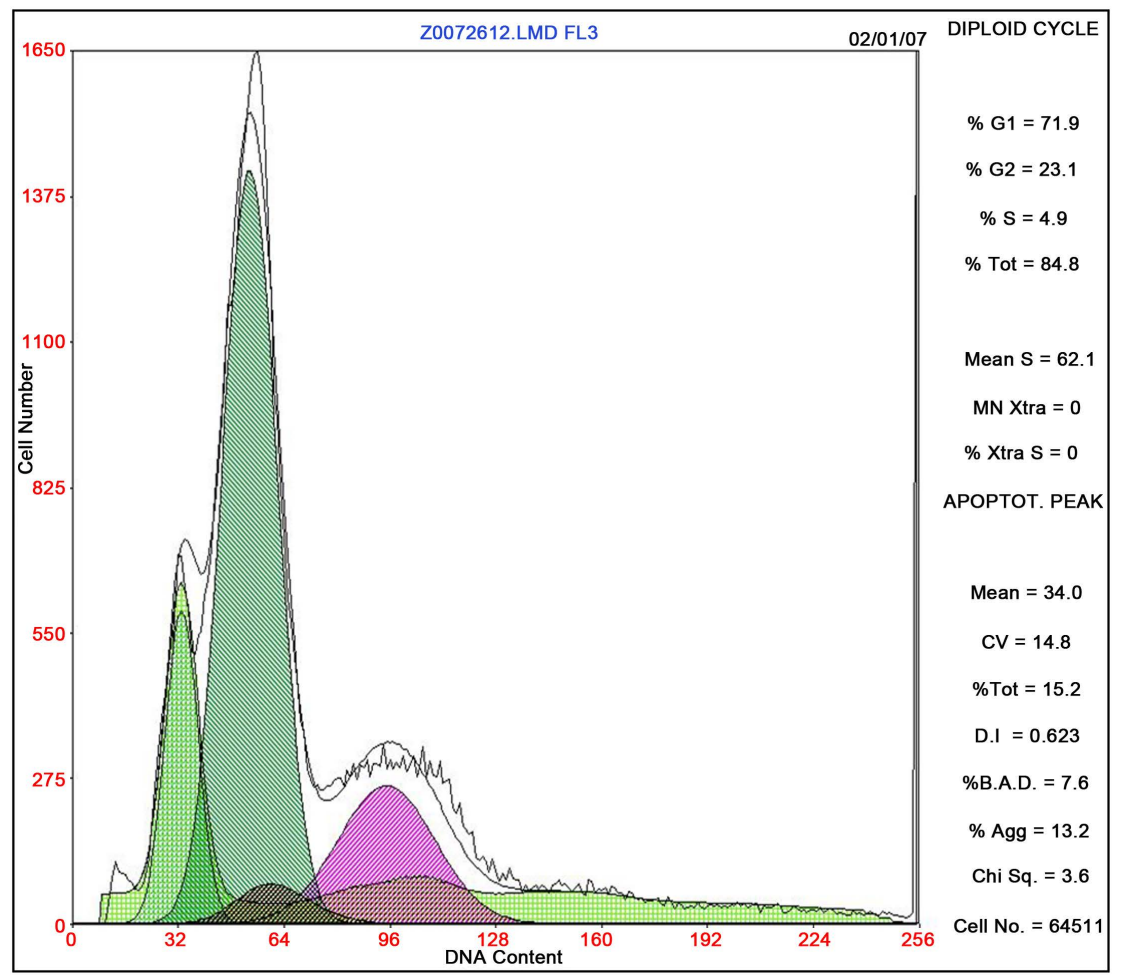

(d)

Figure 2. Scanogram of cell cycle of gastric cancer cells after use of drug by flow cytometry: (a) control group; (b) DDP group; (c) rhGH group; (d) DDP + rhGH group green stands for G0-G1 phase gray stands for S phase; pink stands for G2-M cells in S phase distinctly diminished in DDP group and DDP + rhGH group compared with control group and rhGH group $(p<0.05)$. 


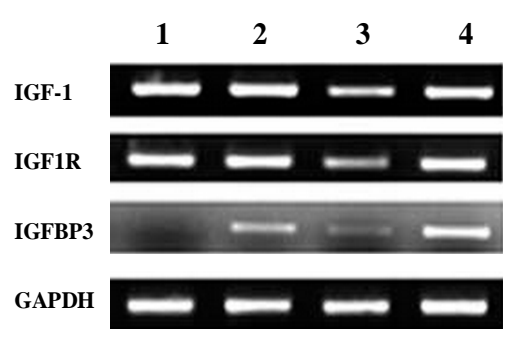

Figure 3. Expression of IGF-I, IGF-IR and IGFBP-3mRNA in tumor by RT-PCR. 1: control group, 2: DDP group, 3: rhGH group, 4: DDP + rhGH group. Expression of IGFBP-3 mRNA obviously raised in DDP group, rhGH group and DDP + rhGH group compared with control group and it obviously raised in DDP + rhGH group compared with other groups $(p<0.05)$.

The growth hormone-insulin-like growth factor axis (GH-IGFs) contains GH, IGFs, IGFR, IGFBP, and IGFBP protease. IGF-1, one of the IGFs, was effective on cell caryocinesia and metabolism. GH could stimulate liver to produce and release IGF, and there was positive correlation between the GH level and the released IGF level. Growth hormone played on its metabolic effects in directly or indirectly by IGF-I [18] [19]. Simultaneously, IGF-I mediated multiple roles of growth hormone promoting growth and synthesis [20]. Furthermore, both growth hormone and IGF-I have roles of saving lean body tissue and maintaining anabolic effect of protein synthesis [21]-[24].

The GH-IGFs acted as a strong promoter not only on cell proliferation in normal tissue but also on tumor formation, development and transference. In many prospective researches, the investigated people were distributed into different 4 groups by their IGF-I levels, and the tumor such as prostatic carcinoma, lung cancer, rectal cancer and breast cancer occurred double or triple times in the highest IGF-I level group than in the lowest IGF-I level group [25] [26]. IGF-I was detected in almost every normal tissue type, it was positive on cell proliferation and differenciation. IGF-1 was also a strong motigen in tumor tissues, and it was regarded as a messenger of GH which was related with several tumor occurrence [27]. Research has shown IGF-I to stimulate the proliferation of pancreatic [28], colon [29], and breast [30] adenocarcinoma cell lines, with blockade of the IGF-1R leading to a downregulation in growth [28] [31] [32]. Studies about breast [33] and colon cancer [34] have demonstrated higher IGF-I levels to be associated with increased risk of adenocarcinoma development. But in recent researches, it was suggested that GH should act differently in tumor tissues according to the IGF-I gene polymorphism and the tumor tissue type [35]-[37]. In addition, Shitara et al. found that genetic polymorphisms of IGF-I may have a substantial effect on recurrence for gastric cancer patients who have undergone curative gastrectomy [38]. Felice et al. thought GH action in the T47D cells was independent of changes in IGF-I and IGF-I receptor (IGF-IR) expression and IGF-IR signaling, suggesting that GH can exert direct effects on breast cancer cells [39].

IGFBP included IGFBP-1, 2, 3, 4, 5, 6 and them were separated and were identified, and IGFBP-3 was regarded as the major binding protein. In some special cases, IGFBP-3 could increase the activities of IGF-I by its self-degradation. The dual regulating mechanisms were controlled by IGFBP protease and GH et al. Because IGFBP was more effective than IGF-1R on binding with IGF-I, it should decrease the activity of IGF-I by the way of competitive inhibition. Besides, IGFBP should suppress cell growth directly. In tumor tissue, the level of IGF-I and IGFBP was effective on tumor occurrence, development, and prognosis, as well as the ratio between IGF-I and IGFBP. It was reported in a research of tumor-bearing mice that the tumor grew little when the mice had ingested the compound protein of IGF-I and IGFBP-3 while the protein production and nutritional status of the mice were improved apparently [40]. It was believed in part of researchers that the proper usage of GH should be related to the treatment periods and the doses of GH as well as the blood level of IGF-1 and IGFBP-3 [41]. It was reported that IGF-1 and IGF-1/IGFBP-3 molar ratio might increase the risk of cancer by increasing mammographic density [42]. In our experiment, the short term treatment of exogenous human growth hormone had increased not only the blood level of IGF-I and IGFBP-3 but also the mRNA expression of IGFBP-3 gene in tumor tissue, but had decreased the rate of IGF-I/IGFBP-3 in the mean time. The increased blood level of IGF-I and IGFBP-3 was also reported in the research of applying rhGH to the dystrophic patients who had been treated with total parenteral nutrition [43].

In the experiment, the short term treatment of exogenous human growth hormone had increased not only the blood level of IGF-I and IGFBP-3 but also the mRNA expression of IGFBP-3 gene in tumor tissue. In the mean 
time, the short term treatment of which rhGH had decreased the rate of IGF-I/IGFBP-3, especially when the treatment was associated with chemical therapy. In our earlier and before researches, it showed that the short term usage of rhGH would not accelerate the growth of human gastric cancer cells [13] [14]. Considering the results of both research, it should be suggested that the short term usage of rhGH would decrease the rate of IGF-I/IGFBP-3 in blood and would increase the protein level of IGFBP-3 in blood and gastric cancer tissue both, and the increased IGFBP-3 would bind with IGF-I as well as competitively inhibited the combination between IGF-I and its receptors, so it was one of mechanism of that the short term usage of rhGH would not accelerate the growth of human gastric cancer cells.

\section{Conclusions}

RhGH in short-time use did not improve proliferation of human gastric cancer cells and its mechanism was possible that rhGH in short-time use raised simultaneously IGF-I and IGFBP-3 of blood serum and increased IGFBP-3 mRNA, but degraded ratio of IGF-I and IGFBP-3 of blood serum in human gastric cancer cells.

Finally, we didn't do some long-term experiments about the research for death of nude mice in DDP group, and this also is the defect of our experiment.

\section{Acknowledgements}

We are grateful to anonymous reviewers for their valuable suggestions and comments. This work was supported by research grants from Natural Science Foundation of China (No. 81060114).

\section{Conflict of Interest}

The authors state no conflict of interest.

\section{Foundation}

Supported by the Natural Science Foundation of China, No. 81060114.

\section{References}

[1] Smith, G.D., Gunnell, D. and Holly, J. (2000) Cancer and Insulin-Like Growth Factor-I. A Potential Mechanism Linking the Environment with Cancer Risk. BMJ, 321, 847-848. http://dx.doi.org/10.1136/bmj.321.7265.847

[2] Samani, A.A., Yakar, S., LeRoith, D. and Brodt, P. (2007) The Role of the IGF System in Cancer Growth and Metastasis: Overview and Recent Insights. Endocrine Reviews, 28, 20-47. http://dx.doi.org/10.1210/er.2006-0001

[3] Bogarin, R. and Steinbok, P. (2009) Growth Hormone Treatment and Risk of Recurrence or Progression of Brain Tumors in Children: A Review. Child's Nervous System, 25, 273-279. http://dx.doi.org/10.1007/s00381-008-0790-6

[4] Losa, M., Gatti, E., Rossini, A. and Lanzi, R. (2008) Replacement Therapy with Growth Hormone and Pituitary Tumor Recurrence: The Relevance of the Problem. Journal of Endocrinological Investigation, 31, 75-78.

[5] Arnold, J.R., Arnold, D.F., Marland, A., Karavitaki, N. and Wass, J.A. (2009) GH Replacement in Patients with NonFunctioning Pituitary Adenoma (NFA) Treated Solely by Surgery Is Not Associated with Increased Risk of Tumor Recurrence. Clinical Endocrinology, 70, 435-438. http://dx.doi.org/10.1111/j.1365-2265.2008.03391.x

[6] Rohrer, T.R., Langer, T., Grabenbauer, G.G., Buchfelder, M., Glowatzki, M. and Dörr, H.G. (2010) Growth Hormone Therapy and the Risk of Tumor Recurrence after Brain Tumor Treatment in Children. Journal of Pediatric Endocrinology and Metabolism, 23, 935-942. http://dx.doi.org/10.1515/jpem.2010.150

[7] Chen, J.Y., Zhang, J., Tan, J., Gan, P., Sun, M. and Chen, X.Z. (1999) Evaluation of Human Growth Hormone on Gastric and Gastric Cancer Patients after Surgery. Chinese Journal of Base and Clinics in General Surgery, 6, 365-367.

[8] Chen, J.Y., Gan, P., Xu, P.Y., Zhang, J., Tan, J. and Sun, M. (2000) Effects of Growth Hormone on Protein Catabolism and Immunologic Function of Postoperative Old Age Patients with Digestive Tract Tumor. Chinese Journal of Gerontology, 20, 162-163.

[9] Harrison, L.E., Blumberg, D., Berman, R., Ng, B., Hochwald, S., Brennan, M.F. and Burt, M. (1996) Effect of Human Growth Hormone on Human Pancreatic Carcinoma Growth, Protein and Cell Cycle Kinetic. Journal of Surgical Research, 61, 317-322. http://dx.doi.org/10.1006/jsre.1996.0123

[10] Tacke, J., Bolder, U., Herrmann, A., Berger, G. and Jauch, K.W. (2000) Long-Term Risk of Gastrointestinal Tumor Recurrence after Postoperative Treatment with Recombinant Human Growth Hormone. JPEN, 24, 140-144. 
http://dx.doi.org/10.1177/0148607100024003140

[11] Bartlett, D.L.T., Stein, P., Torosian, M.H., Philadelphia, P.A. and Camden, N.J. (1995) Effect of Growth Hormone and Protein Intake on Tumor Growth and Host Cachexia. Surgery, 117, 260-267. http://dx.doi.org/10.1016/S0039-6060(05)80199-0

[12] Beentjes, J.A., van Gorkom, B.A., Sluiter, W.J., de Vries, E.G., Kleibeuker, J.H. and Dullaart, R.P. (2000) One Year Growth Hormone Replacement Therapy Does Not Alter Colonic Epithelial Cell Proliferation in Growth Hormone Deficient Adults. Clinical Endocrinology, 52, 457-462. http://dx.doi.org/10.1046/j.1365-2265.2000.00993.x

[13] Blethen, S.L., Allen, D.B., Graves, D., August, G., Moshang, T. and Rosenfeld, R. (1996) Safety of Recombinant Deoxyribonucleic Acid-Derived Growth Hormone: The National Cooperative Growth Study Experience. Journal of Clinical Endocrinology and Metabolism, 81, 1704-1710.

[14] Chen, J.Y., Liang, D.M., Gan, P., Zhang, Y. and Lin, J. (2004) In Vitro Effects of Recombinant Human Growth Hormone on Growth of Human Gastric Cancer Cell Line BGC823 Cells. World Journal of Gastroenterology, 10, 11321136.

[15] Liang, D.M., Chen, J.Y., Zhang, Y., Gan, P., Lin, J. and Chen, A.B. (2006) Effects of Recombinant Human Growth Hormone on Growth of a Human Gastric Carcinoma Xenograft Model in Nude Mice. World Journal of Gastroenterology, 12, 3810-3813.

[16] Osieka, R., Houchens, D.P., Goldin, A. and Johnson, R.K. (1977) Chemotherapy of Human Colon Cancer Xenografts in Athymic Nude Mice. Cancer, 40, 2640-2650.

[17] Lin, Y., Li, S., Cao, P., Cheng, L., Quan, M. and Jiang, S. (2011) The Effects of Recombinant Human GH on Promoting Tumor Growth Depend on the Expression of GH Receptor in Vivo. Journal of Endocrinology, 211, 249-256. http://dx.doi.org/10.1530/JOE-11-0100

[18] Heemskerk, V.H., Daemen, M.A. and Buurman, W.A. (1999) Insulin-Like Growth Factor-I (IGF-I) and Growth Hormone (GH) in Immunity and Inflammation. Cytokine \& Growth Factor Reviews, 10, 5-14.

[19] Berneis, K. and Keller, U. (1996) Metabolic Actions of Growth Hormone: Direct and Indirect. Baillière’s Clinical Endocrinology and Metabolism, 10, 337-352. http://dx.doi.org/10.1016/S0950-351X(96)80470-8

[20] LeRoith, D. and Yakar, S. (2007) Mechanisms of Disease: Metabolic Effects of Growth Hormone and Insulin-Like Growth Factor I. Nature Clinical Practice. Endocrinology \& Metabolism, 3, 302-310.

[21] Hayes, V.Y., Urban, R.J., Jiang, J., Marcell, T.J., Helgeson, K. and Mauras, N. (2001) Recombinant Human Growth Hormone and Recombinant Human Insulin-Like Growth Factor I Diminish the Catabolic Effects of Hypogonadism in Man: Metabolic and Molecular Effects. Journal of Clinical Endocrinology \& Metabolism, 86, 2211-2219.

[22] Mauras, N. and Haymond, M.W. (2005) Are the Metabolic Effects of GH and IGF-I Separable? Growth Hormone \& IGF Research, 15, 19-27.

[23] Mauras, N., Martinez, V., Rini, A. and Guevara-Aguirre, J. (2000) Recombinant Human Insulin-Like Growth Factor Has Significant Anabolic Effects in Adults with Growth Hormone Receptor Deficiency: Studies on Protein, Glucose, and Lipid Metabolism. Journal of Clinical Endocrinology \& Metabolism, 85, 3036-3042.

[24] Shimoda, N., Tashiro, T., Yamamori, H., Takagi, K., Nakajima, N. and Ito, I. (1997) Effects of Growth Hormone and Insulin-Like Growth Factor I on Protein Metabolism, Gut Morphology, and Cell-Mediated Immunity in Burned Rats. Nutrition, 13, 540-516.

[25] Shaneyfelt, T., Husein, R., Bubley, G. and Mantzoros, C.S. (2000) Hormonal Predictors of Prostate Cancer: A Meta-Analysis. Journal of Clinical Oncology, 18, 847-853.

[26] Toniolo, P., Bruning, P.F., Akhmedkhanov, A., Bonfrer, J.M., Koenig, K.L., Lukanova, A., Shore, R.E. and ZeleniuchJacquotte, A. (2000) Serum Insulin-Like Growth Factor-I and Breast Cancer. International Journal of Cancer, 88, 828832. http://dx.doi.org/10.1002/1097-0215(20001201)88:5<828::AID-IJC22>3.0.CO;2-8

[27] Ibrahim, Y.H. and Yee, D. (2004) Insulin-Like Growth Factor-I and Cancer Risk. Growth Hormone \& IGF Research, 14, 261-269. http://dx.doi.org/10.1016/j.ghir.2004.01.005

[28] Tomizawa, M., Shinozaki, F., Sugiyama, T., Yamamoto, S., Sueishi, M. and Yoshida, T. (2010) Insulin-Like Growth Factor-I Receptor in Proliferation and Motility of Pancreatic Cancer. World Journal of Gastroenterology, 16, 18541858. http://dx.doi.org/10.3748/wjg.v16.i15.1854

[29] Koenuma, M., Yamori, T. and Tsuruo, T. (1989) Insulin and Insulin-Like Growth Factor I Stimulate Proliferation of Metastatic Variants of Colon Carcinoma 26. Cancer Science, 80, 51-58. http://dx.doi.org/10.1111/j.1349-7006.1989.tb02244.x

[30] Lippman, M.E. (1985) Growth Regulation of Human Breast Cancer. Clinical Research, 33, 375-382.

[31] Li, S.L., Liang, S.J., Guo, N., Wu, A.M. and Fujita-Yamaguchi, Y. (2000) Single-Chain Antibodies against Human Insulin-Like Growth Factor I Receptor: Expression, Purification, and Effect on Tumor Growth. Cancer Immunology, 
Immunotherapy, 49, 243-252. http://dx.doi.org/10.1007/s002620000115

[32] Reinmuth, N., Liu, W., Fan, F., Jung, Y.D., Ahmad, S.A., Stoeltzing, O., Bucana, C.D., Radinsky, R. and Ellis, L.M. (2002) Blockade of Insulin-Like Growth Factor I Receptor Function Inhibits Growth and Angiogenesis of Colon Cancer. Clinical Cancer Research, 8, 3259-3569.

[33] Key, T.J., Appleby, G.N., Reeves, G.K. and Roddam, A.W. (2010) Insulin-Like Growth Factor I (IGF1), IGF Binding Protein 3 (IGFBP3), and Breast Cancer Risk: Pooled Individual Data Analysis of 17 Prospective Studies. Lancet Oncology, 11, 530-542. http://dx.doi.org/10.1016/S1470-2045(10)70095-4

[34] Ma, J., Pollak, M.N., Giovannucci, E., Chan, J.M., Tao, Y., Hennekens, C.H. and Stampfer, M.J. (1999) Prospective Study of Colorectal Cancer Risk in Men and Plasma Levels of Insulin-Like Growth Factor (IGF)-I and IGF-Binding Protein-3. Journal of the National Cancer Institute, 91, 620-625. http://dx.doi.org/10.1093/jnci/91.7.620

[35] Cleveland, R.J., Gammon, M.D., Edmiston, S.N., Teitelbaum, S.L., Britton, J.A., Terry, M.B., Eng, S.M., Neugut, A.I., Santella, R.M. and Conway, K. (2006) IGF1 CA Repeat Polymorphisms, Lifestyle Factors and Breast Cancer Risk in the Long Island Breast Cancer Study Project. Carcinogenesis, 27, 758-765. http://dx.doi.org/10.1093/carcin/bgi294

[36] Zecevic, M., Amos, C.I., Gu, X., Campos, I.M., Jones, J.S., Lynch, P.M., Rodriguez-Bigas, M.A. and Frazier, M.L. (2006) IGF1 Gene Polymorphism and Risk for Hereditary Nonpolyposis Colorectal Cancer. Journal of the National Cancer Institute, 98, 139-143. http://dx.doi.org/10.1093/jnci/djj016

[37] McGrath, M., Lee, I.M., Buring, J. and De Vivo, I. (2011) Common Genetic Variation within IGFI, IGFII, IGFBP-1, and IGFBP-3 and Endometrial Cancer Risk. Gynecologic Oncology, 120, 174-178. http://dx.doi.org/10.1016/j.ygyno.2010.10.012

[38] Shitara, K., Ito, S., Misawa, K., Ito, Y., Ito, H., Hosono, S., Watanabe, M., Tajima, K., Tanaka, H., Muro, K. and Matsuo, K. (2012) Genetic Polymorphism of IGF-I Predicts Recurrence in Patients with Gastric Cancer Who Have Undergone Curative Gastrectomy. Annals of Oncology, 23, 659-664. http://dx.doi.org/10.1093/annonc/mdr293

[39] Felice, D.L., El-Shennawy, L., Zhao, S., Lantvit, D.L., Shen, Q., Unterman, T.G., Swanson, S.M. and Frasor, J. (2013) Growth Hormone Potentiates 17 $\beta$-Estradiol-Dependent Breast Cancer Cell Proliferation Independently of IGF-I Receptor Signaling. Endocrinology, 154, 3219-3227. http://dx.doi.org/10.1210/en.2012-2208

[40] Wang, W., Iresjö, B.M., Karlsson, L. and Svanberg, E. (2000) Provision of rhIGF-I/IGFBP-3 Complex Attenuated Development of Cancer Cachexia in an Experimental Tumor Model. Clinical Nutrition, 19, 127-132. http://dx.doi.org/10.1054/clnu.1999.0090

[41] Cohen, P., Clemmons, D.R. and Rosenfeld, R.G. (2000) Does the GH-IGF Axis Play a Role in Cancer Pathogenesis? Growth Hormone \& IGF Research, 10, 297-305. http://dx.doi.org/10.1054/ghir.2000.0171

[42] Izzo, L., Meggiorini, M.L., Nofroni, I., Pala, A., De Felice, C., Meloni, P., Simari, T., Izzo, S., Pugliese, F., Impara, L., Merlini, G., Di Cello, P., Cipolla, V., Forcione, A.R., Paliotta, A., Domenici, L. and Bolognese, A. (2012) Insulin-Like Growth Factor-I (IGF-1), IGF-Binding Protein-3 (IGFBP-3) and Mammographic Features. Il Giornale di Chirurgia, 33, 153-162.

[43] Justová, V., Lacinová, Z., Melenovský, V., Marek, J., Holly, J.M. and Hass, T. (2001) The Changes of IGF Binding Proteins after rhGH Administration to Patients Totally Dependent on Parenteral Nutrition. Growth Hormone \& IGF Research, 11, 407-415. http://dx.doi.org/10.1054/ghir.2001.0257 
Scientific Research Publishing (SCIRP) is one of the largest Open Access journal publishers. It is currently publishing more than 200 open access, online, peer-reviewed journals covering a wide range of academic disciplines. SCIRP serves the worldwide academic communities and contributes to the progress and application of science with its publication.

Other selected journals from SCIRP are listed as below. Submit your manuscript to us via either submit@scirp.org or Online Submission Portal.
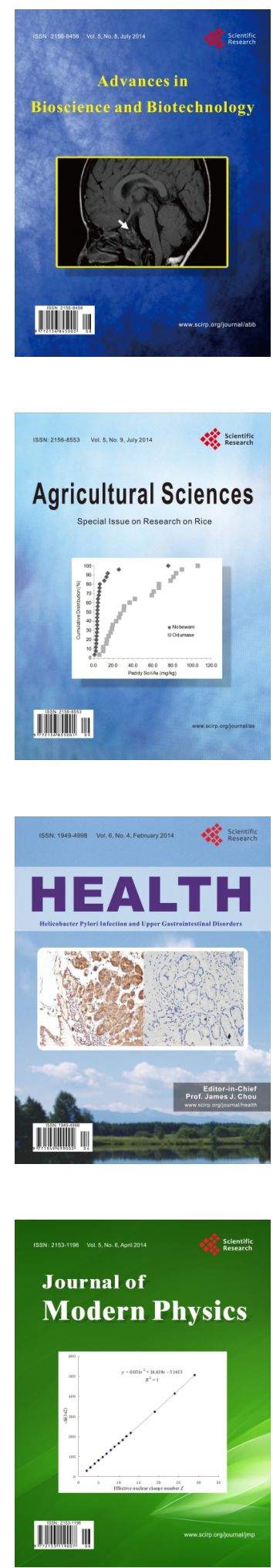
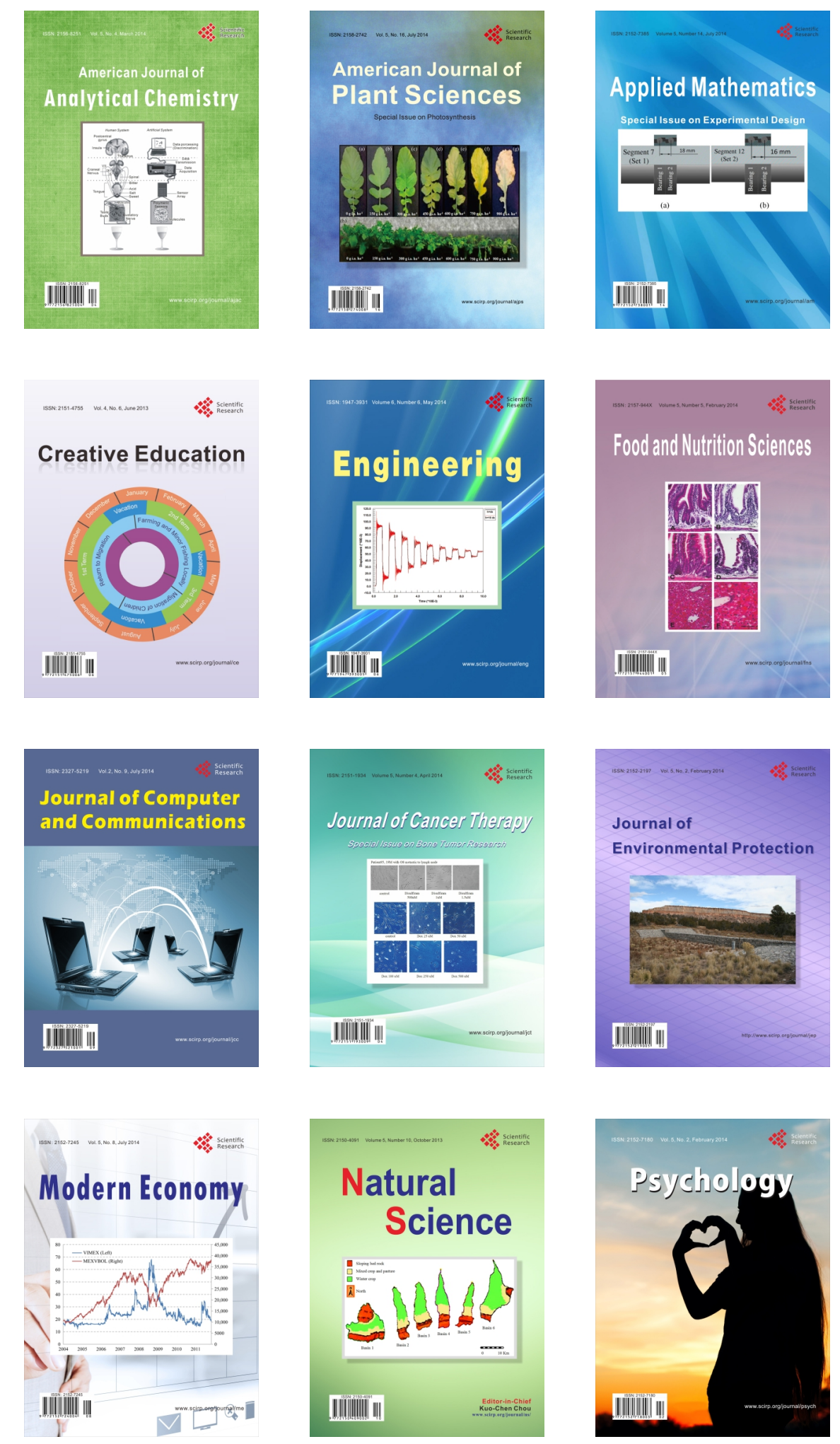